\title{
In Patients Who Underwent Total Thyroidectomy Some Non-Steroidal Anti- inflammatory Drugs Effects on Thyroid Replacement Therapy
}

\author{
Süleyman Kargin ${ }^{1^{*}}$, Didem Tastekin ${ }^{2}$, Azamet Cezik ${ }^{3}$, Murat Cakir ${ }^{1}$, Kemal Kılıç$^{4}$, M Sinan lyisoy $^{5}$ and Tevfik Küçükkartallar $^{1}$ \\ ${ }^{1}$ Necmettin Erbakan University, Meram Medical Faculty, Department of General Surgery, Konya, Turkey \\ ${ }^{2}$ Necmettin Erbakan University, Meram Medical Faculty, Department of Medical Oncology, Konya, Turkey \\ ${ }^{3}$ Çorlu State Hospital Çorlu, Tekirdağ \\ ${ }^{4}$ Kartal State Hospital, Department of General Surgery, Istanbul, Turkey \\ ${ }^{5}$ Necmettin Erbakan University, Meram Medical Faculty, Department of Statistic, Konya, Turkey
}

*Corresponding author: Süleyman Kargin, Konya University, Meram Medical Faculty, Department of General Surgery, Konya- 42080 , Turkey, Tel: 90 332 2236123; Fax: 90332 2236182; E-mail: drs.kargin@hotmail.com

Received Date: 4 March 2014, Accepted Date: 13 March 2014, Published Date: 20 March 2014

Copyright: ( $) 2014$ Süleyman K, et al. This is an open-access article distributed under the terms of the Creative Commons Attribution License, which permits unrestricted use, distribution, and reproduction in any medium, provided the original author(s) and source are credited.

Abstract
Objective
Non-steroid anti-inflammatory drugs can change serum thyroid hormone concentrations by binding to serum
proteins. If misunderstood, this situation can give way to inappropriate diagnoses and faulty treatment planning
for thyroid diseases in clinical practice. The purpose of our study was to investigate the effects of ketoprofen,
lornoxicam, and etofenamate, which are frequently used in clinical practice, on thyroid function tests.
Methodology
The study covered 28 rabbits divided into 4 groups. Groups were administered intramuscular injections daily
for 10 days. Thyroid hormones concentrations were tested in the blood samples end of day 10 .
Results
An increase in free thyroxin level in the lornoxicam group was recorded on day 7 in comparison to other
groups (p=0.015). There was a statistical decrease regarding thyroid stimulant hormone concentration after day 5
in all three groups (Day 5 p=0.000, day $7 \mathrm{p}=0.003$, day $10 \mathrm{p}=0.00$ ).
Conclusion
We believe that previous history of non-steroid anti-inflammatory drug use should be taken into consideration
within the scope of patients' anamneses because non-steroid anti-inflammatory drug use can change the results of
thyroid function tests and this change may lead to misevaluations and mistreatment not only for patients with
thyroid diseases but also for normal patients.

Keywords: Thyroid function; Non-steroidal Drugs; Thyroxin

\section{Introduction}

Many drugs affect the results of thyroid function tests. There are many target areas for the interaction of drugs in thyroid hormone synthesis, transport, metabolism, and absorption. Most of triiodothyronine (T3) and tetraiodothyronine (thyroxin=T4) are carried in circulation by binding to proteins like albumin and transthyretin. A very small portion of thyroid hormones (about $\mathrm{T} 3=0.3 \%$; $\mathrm{T} 4=0.03 \%$ ) are found free in the circulation and carry out biological activities.

Non-Steroidal Anti-Inflammatory Drugs (NSAID) especially affects the binding areas of thyroid hormones' serum proteins and temporarily increases serum thyroid hormone levels. This, in turn, suppresses serum thyroid stimulant hormone (TSH) levels [1,2]. If this condition is misunderstood, the changes that are brought about by drugs can lead to inappropriate diagnosis and faulty treatment planning.

Ketoprofen is a propionic acid derivative. They bind especially to albumin, a serum protein, at a high rate (99\%). Lornoxicam is a nonselective NSAID within the oxicam group with analgesic, antiinflammatory, and antipyretic effects. The reason why Lornoxicam is more attractive than other NSAID drugs in post-op pain treatment is based on the fact that it has a good tolerance profile because of its short half-life, that it has few side effects, and that it has a repeatable dose. Etofenamate has been used as analgesic and anti-inflammatory drug for years. There has been an increase in pre-op and post-op etofenamate use in recent years. Its effect on pain resembles fentanyl and can safely be used [3]. 
Citation: Kargin S, Tastekin D, Cezik A, Cakir M, Kiliç K, et al. In Patients Who Underwent Total Thyroidectomy Some Non-Steroidal Antiinflammatory Drugs Effects on Thyroid Replacement Therapy. Journal of Surgery [Jurnalul de Chirurgie] 2014; 10(1): 21-24. doi:

The purpose of this study is to investigate the effects of three NSAIDs, which are being frequently used in daily practice and frequently prescribed, on rabbits' thyroid function tests.

\section{Methodology}

\section{Rabbits}

The study was conducted upon the consent (2012-45) of Konya Necmettin Erbakan University, Meram Medical Faculty, Experimental Medical Research and Implementation Center's Board of Ethics. The study covered 28 New Zealand rabbits of average age and weight. The rabbits were randomly classified into four groups: Group 1 (control group), Group 2 (Ketoprofen group), Group 3 (Lornoxicam group), and Group 4 (Etofenamate group). The rabbits were administered antiparasitic drugs before the trial and it was determined that they were perfectly healthy clinically. The animals were fed ad libitum by pellet feed twice daily (08:00 and 20:00 h) for ten days and enough clean water was provided.

\section{Trial Procedure}

The experimental animals were equally classified into 4 groups. These were: Group 1 (Control group), Group 2 (Ketoprofen group), Group 3 (Lornoxicam group), and Group 4 (Etofenamate group). The ketoprofen $(n=7)$ (Profenid ampoule, Sanofi Aventis) group received once a day intramuscular injection of $2 \mathrm{mg} / \mathrm{kg}$, the lornoxicam group $(n=7)$ was administered (Xefo vial, Nycomed ASK) once a day intramuscular injection of $0.2 \mathrm{mg} / \mathrm{kg}$, and the etofenamate group $(n=7)$ (Flexo ampoule, SantaFarma) was given once a day intramuscular injection of $15 \mathrm{mg} / \mathrm{kg}$ of their respective drugs for 10 days (Table 1). The control group, on the other hand, was injected 0.3 $\mathrm{mg} / \mathrm{kg} 0.9 \%$ normal saline solution intramuscularly.

Table I: The types of pharmacological agents used their amounts, administration manners, administration frequency, and action time.

\begin{tabular}{|l|l|l|l|l|l|}
\hline $\begin{array}{l}\text { Pharmaco- } \\
\text { logical Agents }\end{array}$ & Dose & $\begin{array}{l}\text { Admin- } \\
\text { istration } \\
\text { Manner }\end{array}$ & Volume & $\begin{array}{l}\text { Admin- } \\
\text { istration } \\
\text { Frequency }\end{array}$ & $\begin{array}{l}\text { Action } \\
\text { Time }\end{array}$ \\
\hline Ketoprofen & $2 \mathrm{mg} / \mathrm{kg}$ & I.M. & $0.04 \mathrm{ml}$ & Daily & $24 \mathrm{Hrs}$ \\
\hline Lornoxicame & $0.2 \mathrm{mg} / \mathrm{kg}$ & I.M. & $0.1 \mathrm{ml}$ & Daily & $24 \mathrm{Hrs}$ \\
\hline Etofenamate & $15 \mathrm{mg} / \mathrm{kg}$ & I.M. & $0.06 \mathrm{ml}$ & Daily & $24 \mathrm{Hrs}$ \\
\hline$\% 0.9$ Saline & $0.3 \mathrm{mg} / \mathrm{kg}$ & I.M. & $0.2 \mathrm{ml}$ & Daily & $24 \mathrm{Hrs}$ \\
\hline
\end{tabular}

During the course of the study, drug administration was carried out every morning at 08:00. Twenty four hours after the first drug administration and before feeding, when the rabbits were hungry, $2 \mathrm{cc}$ of blood was duly drawn from all the animals' vena auricularis into heparinized Eppendorf tubes at 07:00. The samples taken were immediately analyzed by (using Olympus commercial kits) in an Olympus autoanalyzer. Drug administrations were repeated in the same dosage every 24 hours appropriate to each group. On days 2, 3, 5, 7 , and $10 \mathrm{cc}$ of blood samples were drawn from the rabbits using the same method at 07:00. Free T3 (FT3), free T4 (FT4), and TSH levels were tested in all the blood samples.

\section{Statistical Analysis}

The values were given as mean \pm standard deviation and the data collected were compared by using ANOVA and Tukey's HSD (honestly significant difference) tests and covariance analyses. All the statistical analyses were conducted with SPSS 10.0 for Windows package program. Statistical differences were evaluated according to the $\mathrm{p}<0.05$ level.

\section{Results}

No mortality cases and side effects were seen in any group during the course of the study. The changes in FT3, FT4, and TSH levels obtained during drug administration are shown in Table 2.

A significant increase in the FT4 level on day 7 of the treatment was seen in the lornoxicam group in comparison to the control group $(p<0.015)$. Although there was some increase in FT3 levels in all groups during the study, no statistically significant increase was observed among the groups.

Further, a significant decrease in TSH levels was observed after the 5th day among the ketoprofen, lornoxicam, and etofenamate groups (day 5: $\mathrm{p}=0.000$, day 7: $\mathrm{p}=0.003$, day 10: $\mathrm{p}=0.00$ ). While $\mathrm{TSH}<10$ $\mu \mathrm{IU} / \mathrm{ml}$ in all the 35 samples from the control group, TSH $\leq 10 \mu \mathrm{IU} / \mathrm{ml}$ in 31 out of 104 samples from the ketoprofen, lornoxicam, and etofenamate groups. TSH was found to be TSH $\leq 10 \mu \mathrm{IU} / \mathrm{ml}(46.7 \%)$ in 29 out of 62 samples studied on day 5 and later during the course of the treatment in these three groups.

TSH levels in ketoprofen, lornoxicam, and etofenamate groups started to decrease after the first 24 hours in comparison to the control group but statistically significant decrease was seen in all these three groups on day $5(\mathrm{p}<0.015)$. While this decrease in TSH levels continued on days 7 and 10 in the ketoprofen and lornoxicam groups, the significance was lost in the etofenamate group on day 7 , only to come back on day $10 \quad(\mathrm{p}<0.05)$. Moreover, the FT4 level was significantly elevated only in the lornoxicam group on day 7 in comparison to the control group. It persistently continued after day 7 . No significance was observed, however, in FT3 levels in all three groups in comparison to the control group.

While FT4 concentrations were at an average of $17.5 \mu \mathrm{g} / \mathrm{ml}$ (mean $17.2-17.8 \mu \mathrm{g} / \mathrm{ml} \pm \mathrm{SD}$ ) during the whole course of the study in the control group, FT4 concentrations were at an average of $20.4 \mu \mathrm{g} / \mathrm{ml}$ (mean 16.8-23.4 $\mu \mathrm{g} / \mathrm{ml} \pm \mathrm{SD}$ ); $23.6 \mu \mathrm{g} / \mathrm{ml}$ (mean 20.1-25.4 $\mu \mathrm{g} / \mathrm{ml}$ ); and $22.3 \mu \mathrm{g} / \mathrm{ml}$ (mean $21.09-24.8 \mu \mathrm{g} / \mathrm{ml}$ ) for the ketoprofen, lornoxicam, and etofenamate groups, respectively (Table 2 ).

Table II: The effects of Ketoprofen, Lornoxicam, and Etofenamate on thyroid function tests (mean+SD) $(\mathrm{p}<0.05)$.

\begin{tabular}{|c|c|c|c|c|c|c|}
\hline \multirow{2}{*}{ Parameter } & \multicolumn{6}{|c|}{ Days $(n=27)$} \\
\hline & Group & 1 & 3 & 5 & 7 & 10 \\
\hline & Control & $12.00 \pm 1.00$ & $11.86 \pm 1.34$ & $11.57 \pm 1.90$ & $11.14 \pm 1.57$ & $11.67 \pm 1.21$ \\
\hline
\end{tabular}




\begin{tabular}{|c|c|c|c|c|c|c|}
\hline \multirow{4}{*}{$\begin{array}{l}\text { Free T3 } \\
\mathrm{pmol} / \mathrm{L}\end{array}$} & Keto & $10.83 \pm 0.98$ & $12.29 \pm 0.75$ & $12.00 \pm 3.31$ & $12.50 \pm 1.22$ & $13.57 \pm 2.14$ \\
\hline & Lorn & $10.86 \pm 1.06$ & $12.14 \pm 0.90$ & $13.14 \pm 0.90$ & $13.14 \pm 2.11$ & $13.14 \pm 2.41$ \\
\hline & Eto & $11.29 \pm 1.25$ & $11.14 \pm 1.46$ & $11.71 \pm 0.75$ & $12.29 \pm 1.60$ & $12.71 \pm 3.45$ \\
\hline & Total & $11.20 \pm 1.11$ & $11.86 \pm 1.17$ & $12.11 \pm 1.98$ & $12.26 \pm 1.74$ & $12.81 \pm 2.43$ \\
\hline \multirow{5}{*}{$\begin{array}{l}\text { Free T4 } \\
\mathrm{pmol} / \mathrm{L}\end{array}$} & Control & $17.40 \pm 0.54$ & $17.71 \pm 4.30$ & $17.86 \pm 3.07$ & $17.14 \pm 4.22$ & $17.83 \pm 1.94$ \\
\hline & Keto & $16.67 \pm 5.08$ & $19.71 \pm 6.34$ & $20.29 \pm 4.49$ & $22.17 \pm 4.95$ & $23.29 \pm 6.52$ \\
\hline & Lorn & $20.00 \pm 4.20$ & $23.43 \pm 5.88$ & $24.14 \pm 2.96$ & $25.43 \pm 3.86$ & $25.14 \pm 3.33$ \\
\hline & Eto & $21.14 \pm 5.90$ & $22.14 \pm 6.14$ & $22.29 \pm 4.68$ & $21.57 \pm 4.42$ & $25.00 \pm 7.39$ \\
\hline & Total & $19.00 \pm 4.69$ & $20.75 \pm 5.84$ & $21.14 \pm 4.36$ & $21.56 \pm 5.11$ & $23.00 \pm 5.85$ \\
\hline \multirow{5}{*}{$\begin{array}{l}\text { TSH } \\
\mu \mathrm{lU} / \mathrm{ml}\end{array}$} & Control & $11.400 \pm 054$ & $11.57 \pm 0.53$ & $11.71 \pm 0.48$ & $11.42 \pm 0.53$ & $11.83 \pm 0.40$ \\
\hline & Keto & $11.233 \pm 0.25$ & $10.64 \pm 0.69$ & $10.37 \pm 0.38$ & $10.28 \pm 0.91$ & $10.21 \pm 1.06$ \\
\hline & Lorn & $11.129 \pm 0.34$ & $10.61 \pm 0.67$ & $10.22 \pm 0.47$ & $9.77 \pm 0.91$ & $9.58 \pm 0.29$ \\
\hline & Eto & $11.443 \pm 0.52$ & $11.08 \pm 0.62$ & $10.71 \pm 0.75$ & $10.57 \pm 0.53$ & $10.18 \pm 0.91$ \\
\hline & Total & $11.29 \pm 0.42$ & $10.97 \pm 0.71$ & $10.75 \pm 0.78$ & $10.52 \pm 0.93$ & $10.40 \pm 1.08$ \\
\hline
\end{tabular}

It was observed that the drugs administered to the groups, except for the control group, had effects on FT4 and TSH levels. The lornoxicam group, however, proved to be the only group which had significant increase in FT4 levels among the groups studied. Further, it has more effects on FT4 and TSH levels. Etofenamate is less effective on thyroid function tests in comparison to the others among the groups studied. No significant effect of the drug on the FT3 levels of the groups was found.

\section{Discussion}

NSAIDs have been used in pain treatment since ancient ages. Awareness about the risks and side effects of the NSAIDs, however, has recently been on the rise [4]. These types of drugs are prescribed for all painful conditions especially for joint pain and headaches. It has been reported that lornoxicam provided better pain control during the follow-ups after oral surgery and thyroidectomy and had a longer action time [5]. NSAIDs do not only have hepatic side effects but also gastrointestinal, cardiovascular, renal, hematological, and endocrinological side effects.

Drug use may have in vitro or in vivo effects on thyroid tests and/ or thyroid functions [6]. Drugs affect thyroid functions by changing the TSH level through affecting thyroid hormone secretion or hormone metabolism. While some drugs lead to TSH suppression by decreasing TBG concentration or decreasing the binding of FT4 to TBG, some others cause an elevation in TSH levels by bringing about an increase in TBG [7].

Subclinical hyperthyroidism is defined as the case where TSH level is low while FT3 and FT4 are observed in normal concentrations in the presence of drug use that inhibits TSH secretion like hypothalamic or hypophyseal disease or glucocorticoid and dopamine [8]. The prevalence of subclinical hyperthyroidism in the general public is about $3 \%$ and this rate increases for male and female patients who are over 65 years of age [9]. It is generally seen in relation to endogenous reasons. It has been shown that some NSAIDs changed the results of thyroid function test in human beings because the thyroid hormones in circulation bind to serum binding proteins at a high rate and various NSAIDs may change the binding areas of thyroid hormones on serum proteins $[2,10,11]$. Through the inhibition of 5 ' deiodinase enzyme in peripheral tissues, the transformation of Thyroxine (T4) into Triiodothyronine (T3) can be changed $[12,13]$. When there are abnormalities in thyroid binding proteins, the free functions of thyroid hormones reflect their physiological effect better than their total fractions [14]. Thus, miscalculations can be made in the measurement of thyroid hormones in blood. In studies conducted with humans, it has been shown that NSAIDs had significant effects on thyroid functions and that they led to wrong thyroid results and wrong treatment decisions [15,16]. There are many articles which demonstrated that treatment with salicylates in therapeutic doses in the short term caused increases in serum free thyroid hormone concentration and suppression of TSH. The FT4 level can vary due to the use of various non-steroids [2,17]. Some studies reported that drugs which have a similar effect like indomethacin and diclofenac sodium, meclofenamic acid, fenclofenac, phenylbutazone, ibuprofen, and paracetamol increased free T3 and T4 levels by inhibiting the binding of T3 and T4 to plasma proteins [18-23]. For instance, there is an article which showed that a single dose of aspirin use acutely increased free thyroid hormone level by 2-3 times [24]. In our study we investigated the effects of ketoprofen, lornoxicam, and etofenamate, which we frequently use in clinical practice, on thyroid function tests. It was seen that an increase started in the groups within the first 24 hours. The FT4 level, however, was significantly elevated only in the lornoxicam group on day 7. On the other hand, TSH suppression was observed in the ketoprofen and lornoxicam groups on days 5,7 , and 10 while it was observed on days 5 and 10 in the etofenamate group. 
TSH is the first thyroid function test referred to by clinicians. Studies have shown that TSH is both a rapid and inexpensive diagnostic method in showing the right diagnosis [25]. Abnormal TSH level in patients receiving thyroxin treatment points out to inadequate treatment or overdose treatment. The main hormone responsible for thyroid functions in the body is T3. The fact that T3 levels are within normal limits although thyroxin is low may be enough for cases to maintain thyroid functions. T4's capacity for serum binding decreases as a result of the increase in environmental transformation, thus, FT3 values are generally observed to be normal. TSH is used only for initial screening in many clinics because it has a high sensitivity level for thyroid functions. The use of only FT3 and FT4 results are not recommended because they cannot determine subclinical thyroid dysfunctions. Therefore, it would be more appropriate to study FT3 and FT4 concentrations of TSH in combination to evaluate thyroid functions. FT3 levels in our experimental animals were within normal limits and no significant difference was found between the study groups and the control group. This result was in line with literature. The increase in environmental T4's transformation into T3 can be regarded as the reason for this result [24]. Early changes in TSH concentrations and later changes in FT4 concentration, the determination of TSH alongside with FT4 level support the idea that thyroid function tests can be more safely evaluated. FT4 was significantly elevated in the lornoxicam group on day 7 of treatment in comparison to the control group. This difference is more pronounced in the treatment with lornoxicam in comparison to the ketoprofen and etofenamate groups.

In conclusion, since NSAIDs are commonly used in clinical practice and prescribed by all physicians for different reasons, we believe that the use of these drugs may lead to changes in thyroid function tests, may cause misunderstandings especially in the cases of individuals with no thyroid problems, and may also lead to wrong dose regulation for the L-thyroxin drug used by patients with previous history of total thyrodectomy procedure. Specifically when the thyroid function tests of such patients are evaluated, their NSAID histories should also be evaluated and should be taken into consideration when initiating treatment. Our study covered the 10-day treatment follow-up of animals which were administered three non-steroid drugs. We, however, think that such studies should cover a longer period of time and the drugs' effects on humans should also be investigated.

\section{Acknowledgments}

Thanks Dr. Adnan Kaynak for his contribution.

\section{References}

1. Surks MI, Sievert R (1995) Drugs and thyroid function. N Engl J Med 333: 1688-1694.

2. Davies PH, Franklyn JA (1991) The effects of drugs on tests of thyroid function. Eur J Clin Pharmacol 40: 439-451.

3. Inan A, Surgit O, Sen M, Akpinar A, Bozer M (2009) Etofenamat and anastomoses of the colon in rats. Turk J Med Sci 29: 713-718.

4. Scanzello CR, Moskowitz NK, Gibofsky A (2008) The post-NSAID era: what to use now for the pharmacologic treatment of pain and inflammation in osteoarthritis. Curr Rheumatol Rep 10: 49-56.
5. Byrav PDS, Medhi B, Prakash A, Patyar S, Wadhwa S (2009) Lornoxicam: a Newer NSAID. IJPMR 20: 27-31.

6. Haugen BR (2009) Drugs that suppress TSH or cause central hypothyroidism. Best Pract Res Clin Endocrinol Metab 23: 793-800.

7. Stockigt JR (2001) Free thyroid hormone measurement. A critical appraisal. Endocrinol Metab Clin North Am 30: 265-289.

8. Vanderpump MPJ (2005) The epidemiology of thyroid diseases. In: Braverman LE, Utiger RD (eds).Werner and Ingbar's The Thyroid: A Fundamental and Clinical Text, 9th edn. JB Lippincott-Raven: Philadelphia: $398-496$.

9. Vanderpump MP (2011) The epidemiology of thyroid disease. Br Med Bull 99: 39-51.

10. Wenzel KW (1996) Disturbances of thyroid function tests by drugs. Acta Med Austriaca 23: 57-60

11. Bishnoi A, Carlson HE, Gruber BL, Kaufman LD, Bock JL, et al. (1994) Effects of commonly prescribed nonsteroidal anti-inflammatory drugs on thyroid hormone measurements. Am J Med 96: 235-238.

12. Feldman EC, Nelson RW (1996) Canine and Feline Endocrinology and Reproduction, 2nd ed. Philadelphia, WB Saunders: 68-117.

13. Ferguson DC (1998) The effect of nonthyroidal factors on thyroid function tests in dogs. Compend Contin Educ Pract Vet 10: 1365-1377.

14. Benvenga S, Robbins J (1996) Altered thyroid hormone binding to plasma lipoproteins in hypothyroidism. Thyroid 6: 595-600.

15. Daminet S, Croubels S, Duchateau L, Debunne A, van Geffen C, et al. (2003) Influence of acetylsalicylic acid and ketoprofen on canine thyroid function tests. Vet J 166: 224-232.

16. Panciera DL, Refsal KR, Sennello KA, Ward DL (2006) Effects of deracoxib and aspirin on serum concentrations of thyroxine, 3,5,3'triiodothyronine, free thyroxine, and thyroid-stimulating hormone in healthy dogs. Am J Vet Res 67: 599-603.

17. McConnell RJ (1999) Changes in thyroid function tests during shortterm salsalate use. Metabolism 48: 501-503.

18. Lim CF, Loid NM, Kennedy JA, Topliss DJ, Stokigt JR (1995) Effect of loop diuretics and nonsteroidal antiinflammatory drugs on thyrotropin release by rat anterior pituitary cells in vitro. Metabolism 44: 1008-1012.

19. Morris DD, Garcia M (1983) Thyroid-stimulating hormone: response test in healthy horses, and effect of phenylbutazone on equine thyroid hormones. Am J Vet Res 44: 503-507.

20. Clarck WG, Brater DC, Johnson AR(1988) Thyroid Hormones and Antithyroid Drugs, "Goth's Medical Pharmacology" C.V. Mosby Company, Missouri: 57-66.

21. Boeynaems JM, Van Sande J, Dumont JE (1975) Blocking of dog thyroid secretion in vitro by inhibitors of prostaglandin synthesis. Biochem Pharmacol 24: 1333-1337.

22. Topliss DJ, Hamblin PS, Kolliniatis E, Lim CF, Stockigt JR (1988) Furosemide, fenclofenac, diclofenac, mefenamic acid and meclofenamic acid inhibit specific T3 binding in isolated rat hepatic nuclei. J Endocrinol Invest 11: 355-360.

23. Thompson ME, Orczyk GP, Hedge GA (1977) In vivo inhibition of thyroid secretion by indomethacin. Endocrinology 100: 1060-1067.

24. Larsen PR (1972) Salicylate-induced increases in free triiodothyronine in human serum. Evidence of inhibition of triiodothyronine binding to thyroxine-binding globulin and thyroxine-binding prealbumin. J Clin Invest 51: 1125-1134.

25. Laposata M, Dighe A (2007) "Pre-pre" and "post-post" analytical error: high-incidence patient safety hazards involving the clinical laboratory. Clin Chem Lab Med 45: 712-719. 